Stalwick, J. A., and K. L. Wiebe. 2019. Delivery rates and prey use of Mountain Bluebirds in grassland and clear-cut habitats. Avian Conservation and Ecology 14(1):10. https://doi.org/10.5751/ACE-01333-140110

Copyright (C) 2019 by the author(s). Published here under license by the Resilience Alliance.

Research Paper

\title{
Delivery rates and prey use of Mountain Bluebirds in grassland and clear-cut habitats
}

\author{
Jordyn A. Stalwick ${ }^{1}$ and Karen L. Wiebe ${ }^{1}$ \\ ${ }^{1}$ University of Saskatchewan
}

\begin{abstract}
Clear-cutting of forests results in early successional stages that resemble grasslands, and grassland birds such as Mountain Bluebirds (Sialia currucoides) may settle in these anthropogenically created habitats to breed. Our objective was to determine if parent bluebirds provisioned offspring differently, in terms of amount and quality of prey, in clear-cuts versus grasslands, and how this related to fledgling production. We placed microcameras inside 92 nestboxes during two breeding seasons to film parental food deliveries at sites in central British Columbia. At the young nestling stage $(<5 \mathrm{~d}$ old $)$, there were no significant differences in terms of provisioning rate or the type of prey delivered. Neither the abundance of perches in the habitat nor parental traits such as age or plumage brightness were associated with provisioning. When nestlings were older, parents in clear-cuts delivered slightly larger prey and diets with proportionately more larvae and spiders, the most nutritious taxa. However, delivery rates were $21 \%$ higher in grasslands than in clearcuts. Fledglings in clear-cuts had lighter body mass than those in grasslands, suggesting that the high nutrient content of prey in clearcuts could not compensate for the lower deliveries. Thus, parents in grasslands seem more able to meet the energy demands of large nestlings by incorporating diverse insect taxa into their diet.
\end{abstract}

\section{Fréquence de nourrissage et type de proies du Merlebleu azuré dans les prairies et les parterres de coupe totale}

RÉSUMÉ. À la suite de coupes totales, les premiers stades de succession végétale ressemblent à des prairies naturelles, et les oiseaux de prairie, comme le Merlebleu azuré (Sialia currucoides), peuvent nicher dans ces parterres artificiellement créés. Notre objectif était de déterminer si les merlebleus adultes établis dans des parterres de coupe totale nourrissaient leurs oisillons différemment de ceux établis dans des prairies, en termes de quantité et de qualité de proies, et de comparer la production de jeunes. Nous avons placé des microcaméras à l'intérieur de 92 nichoirs au cours de deux saisons de nidification pour filmer le nourrissage des oisillons par les adultes à des sites localisés dans le centre de la Colombie-Britannique. Au stade précoce des oisillons (âgés de $<5$ jours), il n'y avait pas de différence significative de la fréquence de nourrissage ni du type de proie offerte. Ni la quantité de perchoirs dans l'habitat, ni les traits parentaux tels que l'âge ou la brillance du plumage, n'ont contribué à la fréquence de nourrissage. Lorsque les oisillons étaient plus âgés, les parents de parterres de coupe leur ont apporté des proies légèrement plus grosses, et leur régime alimentaire comportait proportionnellement plus de larves et d'araignées (le taxon le plus nutritionnel). Toutefois, la fréquence de nourrissage était plus élevée (de $21 \%$ ) dans les prairies comparativement aux parterres de coupe. Les jeunes nés dans les parterres de coupe avaient un poids plus faible que ceux nés dans les prairies, ce qui laisse croire que la valeur nutritionnelle élevée des proies dans les parterres ne compensait pas la fréquence de nourrissage plus faible. Ainsi, les parents établis dans les prairies semblaient plus aptes à répondre à la demande énergétique d'oisillons plus gros en incorporant divers taxons d'insectes dans leur régime alimentaire.

Key Words: clear-cut; grassland; Mountain Bluebird; nestling diet; prey use

\section{INTRODUCTION}

For decades, forests in northern temperate regions have been subjected to logging practices that leave clear-cuts on the landscape. Various species of birds that use early-successional or open habitats may settle in clear-cuts and extensive research has focused on their reproductive success in these anthropogenically altered habitats. Many studies have documented increased predation rates on nests in fragmented forest landscapes (e.g., Rudnicky and Hunter 1993, Holt and Martin 1997, De Santo and Willson 2001) but the altered structure and composition of vegetation in clear-cuts could also affect food supply for insectivorous birds (Ibbe et al. 2011, Highland et al. 2013).
Whereas open clear-cuts may superficially resemble natural grasslands, the two habitats may contain different forbs or shrubs and hence different species of arthropod prey. For example, compared to old forests, clear-cuts in Finland had more flowering plants, and as a result, more bumblebees and butterflies (Korpela et al. 2015). Grasslands in Sweden had a greater diversity but a lower abundance of butterfly species than clear-cuts (Jonason et al. 2010) and meadows in Oregon, USA had higher diversity and abundance of moths compared to clear-cuts (Highland et al. 2013).

The Mountain Bluebird (Sialia currucoides) is a migratory, insectivorous cavity-nesting thrush that may settle in clear-cuts 
although its natural habitat is grasslands or burns (Johnson and Dawson 2019). We were interested in whether there were differences in the type or amount of prey bluebirds deliver to offspring in clear-cuts versus in native grasslands. Our goal was not to measure prey selection, which would require assessing the availability of different prey types in the environment, but simply to determine prey use, i.e., what Mountain Bluebird parents delivered to their nestlings in each habitat and how this affected the mass of fledglings. Larvae of various species feature prominently in the diet of many passerine nestlings (Skipper and Kim 2013, Wiebe and Slagsvold 2015, Serrano-Davies and Sanz 2017) and also in Mountain Bluebirds (Johnson and Dawson 2019). One reason why larvae may be sought after is that they lack the long appendages and hard unpalatable chitinous exoskeleton of other insects such as grasshoppers, and are relatively easy to swallow (Herlugson 1982, Bańbura et al. 1999). Several studies have documented that parents feed mostly soft prey such as larvae and spiders during the early stage of the nestling period (Bańbura et al. 1994, Wiebe and Slagsvold 2009), and later may include, or switch to, larger insects such as grasshoppers and beetles to cope with increased energy demands of older nestlings (Pinkowski 1978, Wiebe and Slagsvold 2014).

Nutritional content of arthropod prey is also very important in nestling development. Adult Orthoptera (hereafter grasshoppers) and Lepidopteran larvae have relatively high protein content (Bukkens 1997, Barker et al. 1998) and larvae of Lepidoptera and Coleoptera are high in fat and are calorie-rich (Barker et al. 1998). Donald et al. (2001) reported higher nestling body condition in Skylarks (Alauda arvensis) fed with proportionately more insect larvae. The mass of Blue Tit (Cyanistes caeruleus) nestlings also increased as the proportion of larvae in their diet reached $65 \%$ $75 \%$ (García-Navas et al. 2013). Spiders are also believed to be favored prey for young insectivorous nestlings because they contain an amino acid, taurine, that may aid in brain development (Ramsay and Houston 2003, Arnold et al. 2007). Spiders have a higher protein content than larvae (Ramsay and Houston 2003) and adult Coleoptera (Razeng and Watson 2015), and Blue Tit nestlings that were fed spiders had a higher body condition than those lacking spiders in their diet (Serrano-Davies and Sanz 2017). Blue and Great Tit (Parus major) nestlings that had a diet rich in spiders also had relatively long tarsi (García-Navas et al. 2013), perhaps because the high calcium content in spiders (Graveland and Van Gijzen 1994) increased the rate of skeletal mineralization (Tilgar et al. 2005). Therefore, it seems that larvae and spiders are among the highest nutritional-quality prey for insectivorous, passerine nestlings although grasshoppers, which are high in protein, could be important as the nestlings grow and are able to swallow larger and bulkier prey (Stalwick and Wiebe 2019).

In addition to prey type and size, higher delivery rates to nestlings also tend to increase their growth. Experimental enlargements of brood size have shown that parents of many species of birds increase delivery rate to nestlings, presumably in response to higher brood demands and begging cues from nestlings (Musgrove and Wiebe 2014) to try to maintain the quality of offspring. However, if the demands of the brood are too high, increased delivery rates can be associated with a decrease in prey quality and hence reduced nutrition to nestlings, if parents are overly stressed and spend less time searching out the high-quality prey (Wright et al. 1998, García-Navas and Sanz 2010, Wiebe and Slagsvold 2015). Other features intrinsic to the parent, such as its age and body condition, might also influence delivery rates (Desrochers 1992, Hidalgo-Garcia 2006, Daunt et al. 2007) and so are important to control for when comparing food deliveries in different habitats. Physical characteristics of the habitat itself might also influence hunting success or effort. For example, perches may be beneficial by reducing the energy required for foraging by birds that hunt by a sit-and-scan method such as bluebirds (Power 1980). Finally, increased predation risk may cause parents to decrease the number of visits to a nest (Martin et al. 2000) but depredation rates on nests did not differ between grasslands and clear-cuts in our study (Stalwick 2018) and so predation risk is unlikely to explain any habitat-related patterns of food delivery in our system.

Here, we compare delivery rates, prey types, and prey size brought by male and female Mountain Bluebirds to nestlings in clear-cut versus grassland habitats. We assumed that larvae and spiders were the most nutritious prey items (especially for small nestlings) and that large prey would be most efficient for parents to bring as the nestlings grew. In other work, we documented that about $9 \%$ fewer fledglings were produced from eggs laid in the clear-cut habitat compared to the grassland and the mass of fledglings in clear-cuts was $4 \%$ less (Stalwick 2018). If the anthropogenically created clear-cuts are lower-quality habitats because nestlings there are fed less well, we predicted that either (1) prey quality would be similar between habitats but delivery rates (prey quantity) would be lower in clear-cuts if prey were less abundant there; or (2) prey quality would be lower in clear-cuts and delivery rates would be the same or higher than in grasslands if parents try to compensate. Regarding parental traits, we predicted that older (experienced) parents with higher body conditions and brighter, bluer feathers would deliver prey items at a higher rate than poorer quality parents in both habitats, but that the differences in nestling feeding between high- and low-quality parents would be stronger in clear-cut habitats if foraging is more challenging there. Finally, we examined whether there was an association between the number of perches in the habitat type, foraging behavior, predicting that perches would make hunting more efficient and lead to greater delivery rates.

\section{METHODS}

\section{Study site and study species}

We studied Mountain Bluebirds at three study sites containing 14 clear-cuts and 7 grazed grasslands in central British Columbia during the breeding seasons of 2016 and 2017. Grassland sites were near Riske Creek ( $51^{\circ} 58^{\prime} \mathrm{N}, 122^{\circ} 31^{\prime} \mathrm{W}, 986 \mathrm{~m}$ a.s.l.), 100 Mile House $\left(51^{\circ} 38^{\prime} \mathrm{N}, 121^{\circ} 17^{\prime} \mathrm{W}, 970 \mathrm{~m}\right.$ a.s.1.), and Bridge Lake $\left(51^{\circ}\right.$ $28^{\prime} \mathrm{N}, 120^{\circ} 43^{\prime} \mathrm{W}, 1140 \mathrm{~m}$ a.s.1.) and clear-cuts were at the latter two sites. Grasslands were large areas of public land or ranches ( $>\sim 1000$ ha) with free-range cattle allowed to graze for about six weeks in spring and fall. Grasslands contained a mix of native and introduced grasses and forbs and small clumps of trees including Douglas fir (Pseudotsuga menziesii), trembling aspen (Populus tremuloides), lodgepole pine (Pinus contorta), and white spruce (Picea glauca). Clear-cuts were harvested in forest stands of the same tree species and were between 10-40 ha in size and 
1-6 years postharvest. Over 300 plywood nest boxes were placed $1.5 \mathrm{~m}$ high on retained trees in logging cuts and on fence posts in grasslands. The sites were close enough to each other $(134 \mathrm{~km}$ separating the most distant boxes on the study areas) to experience similar weather patterns, and analyses showed that ambient daily temperatures in May and June, as monitored by iButtons at nest boxes did not differ between sites (ANOVA, F2,29=2.3, P=0.12). All boxes were at least $400 \mathrm{~m}$ apart so intraspecific interactions between bluebird pairs were minimal but there was some competition for boxes with Tree Swallows (Tachycineta bicolor; Wiebe 2016).

Mountain Bluebirds began to settle on the study area around midApril after migration, and laid clutches of five to six eggs on average in May. Only the female incubates, but both sexes provision the offspring with a variety of invertebrate prey, including Lepidoptera (adults and larvae), spiders, Coleoptera (hereafter beetles), grasshoppers, Hymenoptera, Diptera, and sometimes Annelida (Pinkowski 1978, Power 1980, Herlugson 1982). The nestling period lasts between 15 and 22 days (Johnson and Dawson 2019).

\section{Field work and filming}

After nestlings hatched, adults were captured using swing-door traps over the entrance hole to the box and banded with a unique set of aluminum and plastic color bands. The birds were weighed, and six structural body-size variables were taken: head-bill length, ninth primary length, central rectrix length, tarsus length, culmen length, and flattened wing chord. We calculated a single size variable using these six measurements in a principal component analysis separated by sex (Rising and Somers 1989). All size variables loaded positively on the first axis (PCA1), and we calculated a body condition index as the residual of a regression of body mass on PCA1 (Labocha and Hayes 2012, Wiebe and Vitousek 2015). Birds were aged as adults versus yearlings based on molt (Pyle 1997). Finally, we clipped the left wing secondary feather $\mathrm{S} 2$ for analysis of color in the lab.

We also sampled the vegetation and habitat structure on each bluebird territory. Bluebird territories can be larger than 5 ha (Johnson and Dawson 2019) and were too large to sample completely, so for an index of the number of perches in the locality of the nest box, we counted (1) "fence pole-height" structures 1.5$3 \mathrm{~m}$ tall within a radius of $50 \mathrm{~m}$ from the box; (2) perches $\geq 3 \mathrm{~m}$ tall (e.g., trees) within a radius of $100 \mathrm{~m}$ of the box; and (3) perches and bushes that were $0.5-1.5 \mathrm{~m}$ tall encountered while walking four $50 \mathrm{~m}$ transects in cardinal directions from the box. Additionally, we sampled forbs and $\%$ cover within two $1 \mathrm{~m}^{2}$ plots placed $25 \mathrm{~m}$ from the focal nest box (see Appendix 1 for vegetation variables).

On the day of filming, we weighed the nestlings and then placed microcameras (either custom-built motion-triggered digital mini cameras or GOPROs) in the ceiling of each nest box to film parental deliveries and identify the taxa and size of prey delivered during 3-hour filming blocks (see Stalwick and Wiebe 2019). This length of filming was sufficient to capture 1-90 (mean 26) deliveries by parents. We did not start calculating delivery rates (deliveries/hr) until the first visit of a parent to the nest, indicating acclimatization to the camera, and discarded cases with fewer than five deliveries. The size of the prey was calculated by comparing the prey item to the bill of the adult, which was of known size, and using the equation of a cylinder: $\pi *(0.5 \text { width })^{2}$ * length to calculate the volume of the body of insect prey excluding wings and legs (Slagsvold and Wiebe 2007). We filmed at 26 clear-cut boxes and 25 grassland boxes in 2016, and at 25 clear-cut boxes and 16 grassland boxes in 2017. The intent was to film at three nestling stages: early ( $0-4 \mathrm{~d}$ old $)$, middle (5-11 d old), and late ( $\geq 12 \mathrm{~d}$ old) at each box, but cold or rainy weather prevented some filming sessions, so sample sizes differed slightly. Regardless of filming, we weighed nestlings at a total of 100 boxes in the early stage, 101 boxes in the middle stage, and 114 boxes in the late stage across both years.

\section{Color analyses}

We analyzed feather color with an Ocean Optics Flame Miniature Spectrometer and a DH-mini UV-VIS deuterium halogen light source with the integration time set to $325 \mathrm{~ms}$, the average scans to 2 , and the boxcar to 10 . Each feather was placed on a dark, nonreflective surface and we took three readings that were $2.5 \mathrm{~cm}$ from the tip of the feather on the leading edge of the vane, holding the probe at $90^{\circ}$ and $2.5 \mathrm{~mm}$ from the surface. We used the R library "pavo" (Maia et al. 2013) to obtain the variables of brightness, chroma, and hue (Montgomerie 2006, Berzins and Dawson 2016). There were two chroma variables, one for the UV range $(300-400 \mathrm{~nm})$ and one for the visible spectrum in the blue range (400-512 nm), which indicated the relative proportion of light reflected by the feather in their respective ranges relative to the entire spectrum. Brightness was the average amount of light reflected by the feather (\% reflected) on the spectrum within 300 $700 \mathrm{~nm}$. Finally, hue was the wavelength of the maximum reflectance of the feather. Chroma was correlated with brightness and hue, so we only used brightness and hue, which were not correlated, in subsequent analyses.

\section{Statistical analyses}

We used R version 3.4.3 (R Core Team 2017) and report data as means \pm standard error unless indicated otherwise. Previously we showed that the size of prey and delivery rates increased rapidly after nestlings were older than four days (Stalwick and Wiebe 2019) and so we decided to analyze diet and delivery rates using two age classes of nestlings to control for the growth of nestlings: early ( $0-4 \mathrm{~d}$ old) and late ( $\geq 5 \mathrm{~d}$ old $)$. To analyze prey volume, for each age class of nestling, we used a linear mixed effects (LME) model (library "ImerTest"; Kuznetsova et al. 2017) with habitat type (grassland vs. clear-cut), parent sex, and year as fixed effects. The random effect was nest box, and the dependent variable, prey volume, was log-transformed for a normal distribution. Pairwise interactions between all fixed effects were included in initial models but deleted if not significant $(\alpha>0.05)$ to increase power. A different set of LME models was used to determine if parental characteristics (size, body condition, age, feather brightness, and feather hue) were associated with the size of prey delivered. These models (one for each sex) included habitat type, year, and each parental characteristic as fixed effects, and nest box as the random effect.

LMEs for delivery rate included nest box as a random variable, and habitat type, brood size, parent sex, density of perches (fence pole-height + taller perches combined), and year as fixed factors. Because shrub density was strongly related to habitat type, we did 
not enter shrubs as a separate variable in models with habitat. Subsequent models (general linear model) with the same fixed effects were run for the sexes individually in order to investigate traits of the individual (age, condition, and color) in relation to delivery rates. We used t-tests to compare the availability of perches between grassland and clear-cut habitat types directly.

Bluebirds brought many taxa of prey to nestlings (Appendix 2) so to simplify analyses of diet composition, we performed a principal components analysis (PCA) on the proportion of total items per filming session that were within each prey type category. To reduce the zeros in the matrix, taxa of some prey were combined such that the eight categories considered were: spiders, larvae (Lepidopteran and Coleopteran larvae), adult Lepidoptera, Hymenoptera + Diptera, Odonata + cicadas, grasshoppers, beetles, and small soft prey (Ephemeroptera + Hemiptera, +Trichoptera + Formicidae). Paired t-tests on the male and female at a nest box $(n=128)$ showed that the sexes did not differ in the proportions of items in these prey classes (all $P$ $>0.08$ ) and so the PCA scores of diet composition were calculated for the deliveries of both parents combined. General linear models were used to analyze the diet scores on the first two axes of the PCA and explanatory variables were habitat type and year.

For nestling mass, we ran two LMMs, one for the early nestling stage and one for the late nestling stage. The early nestling stage model included habitat, age, and year as the fixed effects and nest box as the random effect. By the late stage, nestlings could be sexed by plumage color and so that model also included nestling sex as a fixed effect.

\section{RESULTS}

The diversity of forb taxa appeared higher in clear-cuts although many plant species were common to both habitats. Clear-cuts had less grass cover than grasslands ( $16 \%$ vs $34 \%$ ) and tended to have more dead wood and less bare ground than grasslands (Appendix 1). Besides grass spp., the most abundant plant family in grasslands was Asteraceae and in clear-cuts it was Rosaceae. In terms of habitat structure, there were more perches $<1.5-\mathrm{m}$ tall in clear-cuts $\left(20.9 / 100 \mathrm{~m}^{2} \pm 1.4\right)$ than in grasslands $\left(2.9 / 100 \mathrm{~m}^{2}\right.$ $\left.\pm 0.7 ; \mathrm{t}_{61}=11.55, P<0.001\right)$ as a result of the higher density of shrubs and slash in clear-cuts. There were also more perches $1.5-$ $3 \mathrm{~m}$ tall in clear-cuts $\left(0.69 / 100 \mathrm{~m}^{2} \pm 0.08\right)$ than in grasslands $\left(0.29 / 100 \mathrm{~m}^{2} \pm 0.01 ; \mathrm{t}_{45}=4.67, P<0.001\right)$ but the density of perches taller than $3 \mathrm{~m}$ (such as trees) did not differ between habitats $\left(\mathrm{t}_{84}=1.60, P=0.113\right)$ and averaged $0.07 / 100 \mathrm{~m}^{2} \pm 0.004$.

\section{Prey volume and type}

Adults in clear-cuts brought larger prey $\left(322 \mathrm{~mm}^{3} \pm 6.8\right)$ than those in grasslands $\left(297 \mathrm{~mm}^{3} \pm 6.1\right)$, and males brought larger prey than females, but these differences were only significant at the older and not younger nestling stage (Fig.1, Table 1). Prey volume increased as nestlings aged in both habitats (Fig. 1). There was a significant interaction between habitat and parent sex in the younger nestling stage (Table 1) and this was because in grasslands, females brought smaller prey than males to small nestlings $\left(\mathrm{F}_{1,686}=5.46, P=0.02\right)$ whereas in clear-cuts, male and female parents brought similar-sized prey items $\left(\mathrm{F}_{1,870}=0.05, P\right.$ $=0.83$ ). With the sexes considered separately, among male parents, neither habitat type nor individual traits such as size, body condition, or feather color were associated with the size of prey he brought at either the young or older nestling stages. However, in the older nestling stage, older males brought larger prey items $\left(389 \mathrm{~mm}^{3} \pm 13.9\right)$ than yearlings $\left(347 \mathrm{~mm}^{3} \pm 16.5\right.$; Table 1). Among females, the effect of habitat was significant for both nestling classes, but only weakly so, and of the individual traits only body size was significant in the older nestling stage, with larger females bringing larger prey.

Fig. 1. Prey volume brought by male and female Mountain Bluebirds (Sialia currucoides) in clear-cuts and grasslands in central British Columbia as determined by video filming inside nest boxes. Top panel is for young nestlings $(0-4 \mathrm{~d}$ old $)$ and bottom panel is for older nestlings ( $\geq 5 \mathrm{~d}$ old). Bars are means + standard error. The number of prey items are above the bars.

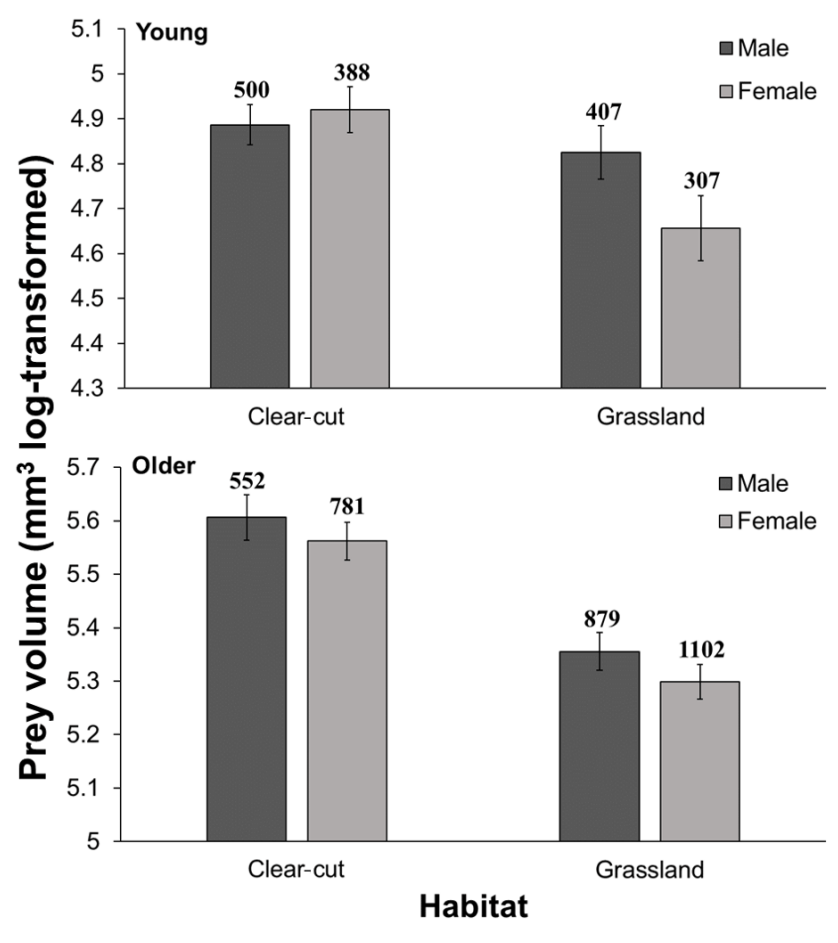

Negative scores on the first axis derived from the PCA (Eigenvalue $1.6,20 \%$ of the variance) indicated a high fraction of larva in the diet whereas positive scores indicated a more varied diet with adult Lepidoptera and grasshoppers (loadings in Table 2). The second axis (PCA2, Eigenvalue 1.5, 19\%) was driven mainly by spiders as indicated by high negative scores on this axis and by beetles (positive scores). Diet composition in terms of these prey types did not differ between habitats at the young nestling stage (Table 3 ). When nestlings were $\geq 5$ days old, analysis of PCA1 scores indicated that adults in clear-cuts brought a higher proportion of larvae than those in grasslands while parents in grasslands brought a more varied diet with more grasshoppers and adult Lepidoptera (Fig. 2, Table 3). At the older nestling stage, spiders formed a higher proportion of the diet in clear-cuts than in grasslands according to analysis of PCA2 scores (Fig. 2, Table 3). Instead of spiders, adults in grasslands switched to incorporating more beetles into the diet. 
Table 1. Linear mixed effects models for prey volume brought by Mountain Bluebirds (Sialia currucoides) nesting in either grasslands or clear-cuts in central British Columbia. Two sets of models were run: one for young nestlings ( $0-4 \mathrm{~d})$ and one for older nestlings $\geq 5$ $\mathrm{d}$. The dependent variable of Prey Volume is for parents pooled (total deliveries). Other models for each sex separately incorporate individual traits of the parents (age, body size, condition, and color). Significant P-values $(<0.05)$ are denoted by *. Nonsignificant (ns) interactions were removed from the final models.

\begin{tabular}{|c|c|c|c|c|c|c|c|c|c|}
\hline \multirow{2}{*}{$\begin{array}{l}\text { Dependent } \\
\text { Variable }\end{array}$} & \multirow[t]{2}{*}{ Model } & \multicolumn{4}{|c|}{ Young nestlings } & \multicolumn{4}{|c|}{ Older nestlings } \\
\hline & & Coefficient $^{\dagger}$ & $\mathrm{DF}$ & $\mathrm{F}$ & $P$ & Coefficient $^{\dagger}$ & $\mathrm{DF}$ & $\mathrm{F}$ & $P$ \\
\hline \multirow[t]{4}{*}{ Prey Volume } & Habitat & $-0.34 \pm 0.15$ (grass) & 1,53 & 2.44 & 0.12 & $-0.20 \pm 0.08$ (grass) & 1,50 & 6.05 & $0.02 *$ \\
\hline & Parent Sex & $-0.03 \pm 0.07$ (male) & 1,1562 & 2.53 & 0.11 & $0.10 \pm 0.04$ (male) & 1,3224 & 7.33 & $0.007 *$ \\
\hline & Year & $-0.09 \pm 0.09(2017)$ & 1,349 & 0.92 & 0.34 & $0.14 \pm 0.05(2017)$ & 1,385 & 6.73 & $0.01 *$ \\
\hline & Habitat * Sex & $0.23 \pm 0.11$ (grass \& male $)$ & 1,1562 & 4.70 & $0.03 *$ & & & & \\
\hline Male's Prey & Habitat & $0.04 \pm 0.21$ (grass) & 1,37 & 0.04 & 0.84 & $-0.12 \pm 0.14$ (grass) & 1,40 & 0.73 & 0.40 \\
\hline \multirow[t]{6}{*}{ Volume } & Male Age & $0.01 \pm 0.34$ (yearling) & 1,43 & $<0.01$ & 0.98 & $-0.53 \pm 0.22$ (yearling) & 1,88 & 5.58 & $0.02 *$ \\
\hline & Male Size & $0.05 \pm 0.08$ & 1,49 & 0.32 & 0.57 & $-0.003 \pm 0.06$ & 1,60 & $<0.01$ & 0.96 \\
\hline & Male Condition & $-0.12 \pm 0.07$ & 1,39 & 3.07 & 0.09 & $<0.001 \pm 0.05$ & 1,54 & $<0.01$ & 1.0 \\
\hline & Male Brightness & $0.11 \pm 0.09$ & 1,41 & 1.58 & 0.22 & $0.004 \pm 0.06$ & 1,71 & 0.01 & 0.94 \\
\hline & Male Hue & $-0.004 \pm 0.007$ & 1,52 & 0.45 & 0.51 & $0.01 \pm 0.006$ & 1,60 & 3.40 & 0.07 \\
\hline & Year & $0.02 \pm 0.18(2017)$ & 1,52 & 0.01 & 0.93 & $0.07 \pm 0.10(2017)$ & 1,130 & 0.50 & 0.48 \\
\hline Female's Prey & Habitat & $-0.44 \pm 0.22$ (grass) & 1,33 & 4.01 & 0.05 & $-0.20 \pm 0.10($ grass $)$ & 1,32 & 4.12 & 0.05 \\
\hline \multirow[t]{6}{*}{ Volume } & Female Age & $0.35 \pm 0.23$ (yearling) & 1,58 & 2.27 & 0.14 & $-0.21 \pm 0.11$ (yearling) & 1,49 & 3.47 & 0.07 \\
\hline & Female Size & $0.14 \pm 0.08$ & 1,63 & 2.88 & 0.09 & $0.12 \pm 0.05$ & 1,66 & 6.26 & $0.02 *$ \\
\hline & Female Condition & $0.06 \pm 0.05$ & 1,109 & 1.34 & 0.25 & $-0.04 \pm 0.03$ & 1,43 & 1.79 & 0.19 \\
\hline & Female Brightness & $0.05 \pm 0.05$ & 1,47 & 1.03 & 0.32 & $0.04 \pm 0.03$ & 1,52 & 1.62 & 0.21 \\
\hline & Female Hue & $-0.01 \pm 0.01$ & 1,60 & 1.64 & 0.21 & $0.002 \pm 0.002$ & 1,80 & 0.67 & 0.41 \\
\hline & Year & $-0.43 \pm 0.17(2017)$ & 1,88 & 6.17 & $0.01 *$ & $0.17 \pm 0.08(2017)$ & 1,67 & 4.33 & $0.04 *$ \\
\hline
\end{tabular}

†Each variable's coefficient estimates (unstandardized) were obtained using the "summary" function in R and the degrees of freedom, F, and $P$-values were obtained using the "anova" function. For categorical variables, the coefficient is calculated for the category in parentheses to compare to the intercept (the category of the variable not indicated in parentheses), but the other columns refer to the categorical variable as a whole.

Table 2. Loadings on the first two axes from a principal component analysis (PCA) on prey types used by Mountain Bluebirds (Sialia currucoides) when feeding nestlings in central British Columbia. The "other" category refers to combined Ephemeroptera, Hemiptera, Trichoptera, and Formicidae.

\begin{tabular}{lcc}
\hline \hline & \multicolumn{2}{c}{ PCA axis } \\
\cline { 2 - 3 } & 1 & 2 \\
\hline Larva & -0.704 & 0.225 \\
Beetle & 0.121 & 0.752 \\
Lepidoptera adult & 0.548 & -0.083 \\
Grasshopper & 0.578 & -0.084 \\
Spider & -0.081 & -0.903 \\
Other & 0.479 & 0.076 \\
Fly/wasp/bee & 0.320 & 0.045 \\
Dragonflies \& cicadas & 0.299 & 0.126 \\
\hline
\end{tabular}

\section{Delivery rates}

Considering the delivery rate to a brood with both parents combined, the density of perches did not affect delivery rates (Table 4). Total deliveries to broods with both parents combined increased with brood size and was $21 \%$ higher in grasslands $(12.4$ $\pm 0.6 \mathrm{prey} / \mathrm{hr})$ than in clear-cuts $(9.9 \pm 0.4 \mathrm{prey} / \mathrm{hr}$; Table 4$)$, although significantly higher only when nestlings were older. In these pooled data, males delivered food more frequently than females at the young nestling stage when females spent time brooding but had a lower delivery rate than females when nestlings were older (Fig. 3, Table 4).
Fig. 2. Diet composition (taxa of insect prey) of Mountain Bluebirds (Sialia currucoides) in central British Columbia as shown by principal components analysis (PCA). Diet was determined for nestlings $\geq 5$ days old by filming at 40 nest boxes in clear-cuts and 35 in grasslands. Insect taxa with the highest loadings are indicated for each axis but refer to Table 2 for the complete axis loadings.

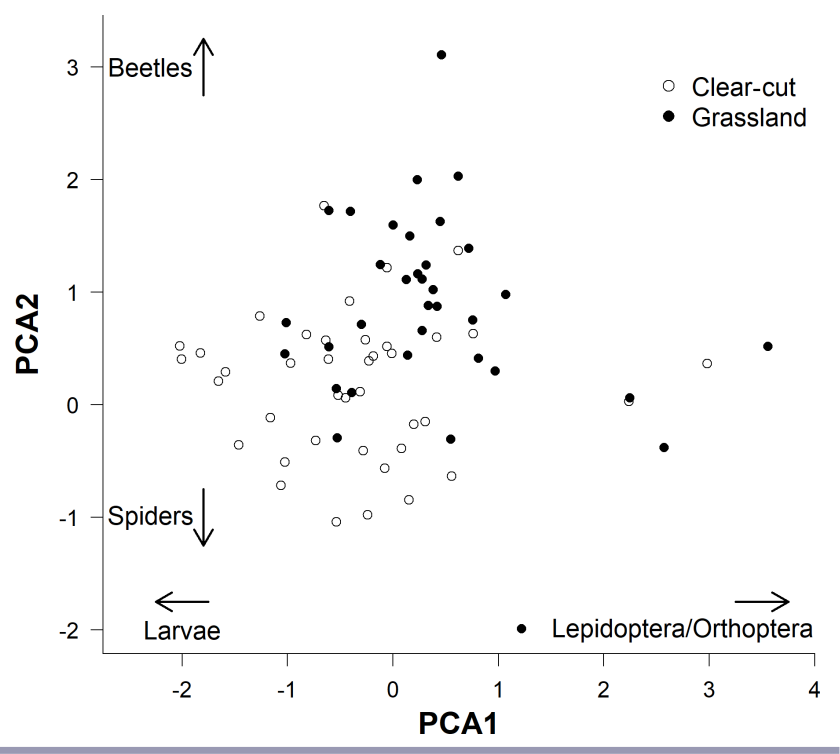


Table 3. General linear models for diet composition (prey types) brought by Mountain Bluebirds (Sialia currucoides) nesting in either grasslands or clear-cuts in central British Columbia. PCA 1 are scores on the first axis of the principle components analysis and PCA 2 is the second axis (for interpretation see Table 2 for loadings on these axes). Two sets of models were run, one for young nestlings aged $0-4 \mathrm{~d}$ and another for older nestlings $\geq 5 \mathrm{~d}$ old. Significant P-values $(<0.05)$ are denoted by *.

\begin{tabular}{|c|c|c|c|c|c|c|c|c|c|}
\hline \multirow{2}{*}{$\begin{array}{l}\text { Dependent } \\
\text { Variable }\end{array}$} & \multirow[t]{2}{*}{ Model } & \multicolumn{4}{|c|}{ Young nestling stage } & \multicolumn{4}{|c|}{ Older nestling stage } \\
\hline & & Coefficient $^{\dagger}$ & DF & $\mathrm{F}$ & $P$ & Coefficient $^{\dagger}$ & DF & $\mathrm{F}$ & $P$ \\
\hline \multirow[t]{2}{*}{ PCA 1} & Habitat & $0.19 \pm 0.25$ (grass) & 1,59 & 1.07 & 0.31 & $0.71 \pm 0.22($ grass $)$ & 1,73 & 11.99 & $<0.001^{*}$ \\
\hline & Year & $-0.38 \pm 0.26(2017)$ & 1,58 & 2.27 & 0.14 & $-0.55 \pm 0.22(2017)$ & 1,72 & 6.38 & $0.014^{*}$ \\
\hline \multirow[t]{2}{*}{ PCA 2} & Habitat & $0.37 \pm 0.23$ (grass) & 1,59 & 2.84 & 0.10 & $0.66 \pm 0.18$ (grass) & 1,73 & 13.78 & $<0.001^{*}$ \\
\hline & Year & $-0.08 \pm 0.24(2017)$ & 1,58 & 0.01 & 0.74 & $0.01 \pm 0.18(2017)$ & 1,72 & 0.01 & 0.94 \\
\hline
\end{tabular}

†Each variable's coefficient estimates (unstandardized) were obtained using the "summary" function in R and the degrees of freedom, F, and $P$-values were obtained using the "anova" function. For categorical variables, the coefficient is calculated for the category in parentheses to compare to the intercept (the category of the variable not indicated in parentheses), but the other columns refer to the categorical variable as a whole.

Fig. 3. Delivery rates of Mountain Bluebird (Sialia currucoides) parents by sex in clear-cuts and grasslands in central British Columbia as determined by filming at nest boxes. Top panel is for young nestlings ( $0-4 \mathrm{~d}$ old $)$ and bottom panel is for older nestlings $\geq 5 \mathrm{~d}$ old. The number of filming events are above the bars.

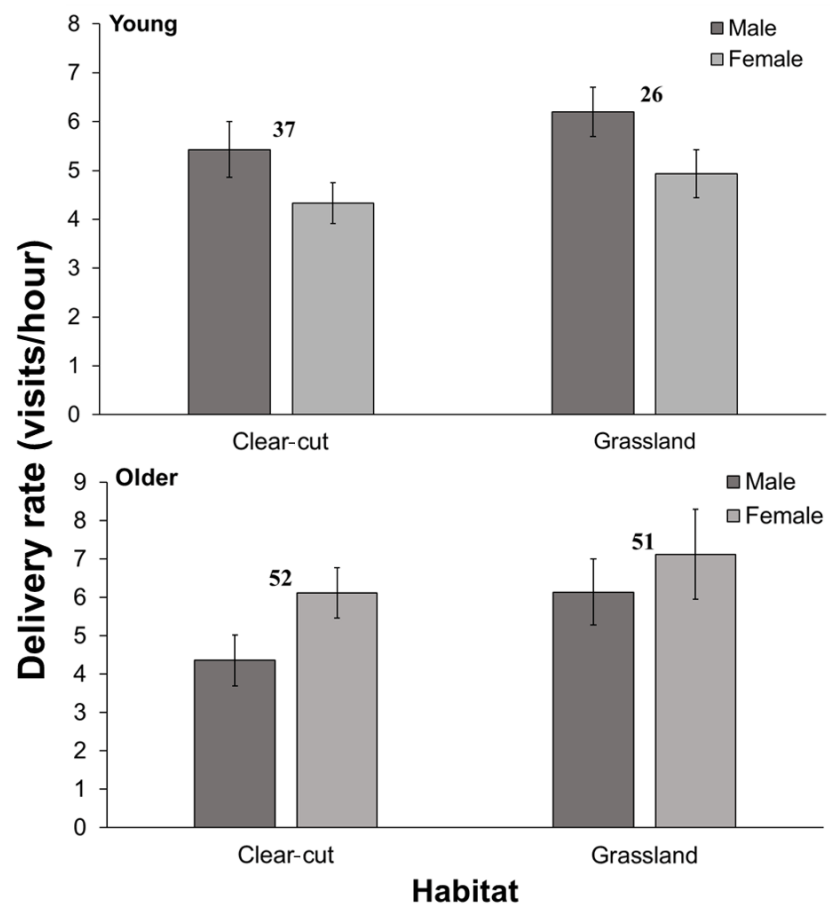

When the delivery rates of the sexes were considered independently, males increased deliveries with increasing brood size and deliveries averaged higher in grasslands than in clear-cuts at the old nestling stage, although not significantly so (Table 4). Among females, delivery rates also increased with brood size and, during the older nesting stage, were affected by a habitat and brood size interaction (Table 4); delivery rates increased with brood size in grasslands but not in clear-cuts. Neither the age nor the color of the plumage was associated with delivery rates for either sex, but body condition of the adult had a complex association with delivery rates. When nestlings were young, delivery rates by males were positively correlated with their own body condition whereas females in good body condition had lower delivery rates. During the older nestling stage, among both sexes, delivery rates were negatively correlated with body condition.

\section{Nestling masses}

The average mass of nestlings in the early nestling stage was 6.9 $\mathrm{g} \pm 0.1$ in both habitats (LMM: $\left.\mathrm{F}_{1,77}=1.57, P=0.21\right)$ and it did not differ between years $\left(\mathrm{F}_{1,363}=0.73, P=0.39\right)$ but did increase with age from day $0-4$ within this period $\left(\mathrm{F}_{1,151}=303, P<0.001\right)$. For mass at the late stage, near the time of fledging when nestling sex could be determined, male nestlings had a higher mass than females (LMM: $\left.\mathrm{F}_{1,425}=14.53, P<0.001\right)$ and the mass of these older nestlings was higher in grasslands than in clear-cuts $\left(\mathrm{F}_{1,84}=\right.$ $6.75, P=0.011$; Fig. 4). However, there was no difference between the two years of study $\left(\mathrm{F}_{1,463}=0.26, P=0.61\right)$ and no interaction between habitat type and fledgling sex.

\section{DISCUSSION}

Prey deliveries of bluebirds to their nestlings differed between clear-cut and grassland habitats, but in a complex way. When nestlings were young, the type and rate of prey delivered by parents in each habitat type did not differ, suggesting that parents could meet the nutritional demands of young nestlings equally well in either habitat. However, with older nestlings, parents in grasslands increased delivery rates apparently by incorporating a more diverse diet. Thus, although the diet of older nestlings in clear-cuts contained proportionally more of the large, nutritious prey (larvae and spiders), the total amount of delivered food was less in clear-cuts because nestlings there fledged with lower mass compared to those in grasslands.

The lower fledging mass of nestlings in clear-cuts shows that parents in the anthropogenically created habitat provided less food to nestlings but this could be a result of several proximate mechanisms. Because predation rates on nests did not differ between grasslands and clear-cuts in our study (Stalwick 2018), 
Table 4. Models for prey delivery rates to nestlings by Mountain Bluebirds (Sialia currucoides) in grassland or clear-cut habitats in central British Columbia. Pooled rate is for both parents and uses a linear mixed model and the models separated by sex use general linear models. Models were run for each of the young nestling $(0-4 \mathrm{~d}$ old $)$ and older nestling $(\geq 5 \mathrm{~d})$ stages. Significant $\mathrm{P}$-values $(<0.05)$ are denoted by *.

\begin{tabular}{|c|c|c|c|c|c|c|c|c|c|}
\hline \multirow{2}{*}{$\begin{array}{l}\text { Dependent } \\
\text { Variable }\end{array}$} & \multirow[t]{2}{*}{ Model } & \multicolumn{4}{|c|}{ Young nestling stage } & \multicolumn{4}{|c|}{ Older nestling stage } \\
\hline & & Coefficient $^{\dagger}$ & DF & $\mathrm{F}$ & $P$ & Coefficient $^{\dagger}$ & DF & $\mathrm{F}$ & $P$ \\
\hline \multirow[t]{5}{*}{ Pooled Rate } & Habitat & $1.13 \pm 0.57$ (grass) & 1,48 & 3.86 & 0.06 & $1.84 \pm 0.52$ (grass) & 1,194 & 12.42 & $<0.001 *$ \\
\hline & Brood Size & $0.75 \pm 0.26$ & 1,64 & 8.20 & $0.005^{*}$ & $1.03 \pm 0.22$ & 1,194 & 22.15 & $<0.001 *$ \\
\hline & Parent Sex & $1.08 \pm 0.47$ (male) & 1,67 & 5.38 & $0.02 *$ & $-1.53 \pm 0.45$ (male) & 1,194 & 11.41 & $<0.001 *$ \\
\hline & \# of Perches & $21.12 \pm 70.56$ & 1,48 & 0.09 & 0.77 & $13.08 \pm 48.63$ & 1,194 & 0.07 & 0.79 \\
\hline & Year & $-0.84 \pm 0.52(2017)$ & 1,92 & 2.59 & 0.11 & $0.30 \pm 0.46(2017)$ & 1,194 & 0.41 & 0.52 \\
\hline \multirow[t]{7}{*}{ Male Rate } & Habitat & $0.90 \pm 1.06$ (grass) & 1,44 & 0.61 & 0.44 & $1.39 \pm 0.78$ (grass) & 1,77 & 3.22 & 0.08 \\
\hline & Brood Size & $0.94 \pm 0.51$ & 1,43 & 2.05 & 0.16 & $0.99 \pm 0.38$ & 1,76 & 12.26 & $<0.001 *$ \\
\hline & Male Age & $0.22 \pm 1.81$ (yearling $)$ & 1,42 & 1.96 & 0.17 & $0.35 \pm 1.60$ (yearling) & 1,75 & 0.75 & 0.39 \\
\hline & Male Condition & $\overline{0} .75 \pm 0.39$ & 1,41 & 4.39 & $0.04 *$ & $-0.86 \pm 0.34$ & 1,74 & 6.01 & $0.02 *$ \\
\hline & Male Brightness & $0.0003 \pm 0.46$ & 1,40 & $<0.01$ & 0.99 & $-0.25 \pm 0.36$ & 1,73 & 1.23 & 0.27 \\
\hline & Male Hue & $0.06 \pm 0.04$ & 1,39 & 1.83 & 0.18 & $-0.03 \pm 0.04$ & 1,72 & 0.70 & 0.41 \\
\hline & Year & $-1.35 \pm 1.05(2017)$ & 1,38 & 1.68 & 0.20 & $-0.73 \pm 0.78(2017)$ & 1,71 & 0.86 & 0.36 \\
\hline \multirow[t]{8}{*}{ Female Rate } & Habitat & $0.65 \pm 0.75$ (grass) & 1,51 & 0.12 & 0.74 & $-8.79 \pm 3.15$ (grass) & 1,77 & 2.53 & 0.12 \\
\hline & Brood Size & $0.66 \pm 0.36$ & 1,50 & 4.69 & $0.04 *$ & $-0.06 \pm 0.49$ & 1,76 & 12.29 & $<0.001^{*}$ \\
\hline & Female Age & $-1.18 \pm 0.87($ yearling $)$ & 1,49 & 1.12 & 0.29 & $-1.74 \pm 0.89$ (yearling) & 1,75 & 0.50 & 0.48 \\
\hline & Female Condition & $-0.43 \pm 0.21$ & 1,48 & 4.47 & $0.04 *$ & $-0.16 \pm 0.26$ & 1,74 & 0.07 & 0.79 \\
\hline & Female Brightness & $0.09 \pm 0.20$ & 1,47 & 0.39 & 0.54 & $0.35 \pm 0.21$ & 1,73 & 3.16 & 0.08 \\
\hline & Female Hue & $-0.01 \pm 0.02$ & 1,46 & 0.04 & 0.85 & $0.03 \pm 0.02$ & 1,72 & 2.46 & 0.12 \\
\hline & Year & $-0.83 \pm 0 . \overline{7} 4(2017)$ & 1,45 & 1.28 & 0.26 & $0.78 \pm 0.69(2017)$ & 1,71 & 0.64 & 0.43 \\
\hline & Habitat $*$ Brood Size & & & & & $2.24 \pm 0.65$ (grass) & 1,70 & 11.77 & $0.001 *$ \\
\hline
\end{tabular}

†Each variable's coefficient estimates (unstandardized) were obtained using the "summary" function in R and the degrees of freedom, F, and $P$-values were obtained using the "anova" function. For categorical variables, the coefficient is calculated for the category in parentheses to compare to the intercept (the category of the variable not indicated in parentheses), but the other columns refer to the categorical variable as a whole.

Fig. 4. The mean mass of Mountain Bluebird (Sialia currucoides) nestlings at two nestling stages (early: 0-4 d old; late: $\geq 12 \mathrm{~d}$ old) in both habitat types in central British Columbia. Sexes were pooled in the early nestling stage and separated in the late nestling stage. The star indicates a significant difference $(\mathrm{P}<0.05)$ between habitats in the late nestling stage (fledglings). Sample sizes of nestlings are above the columns.

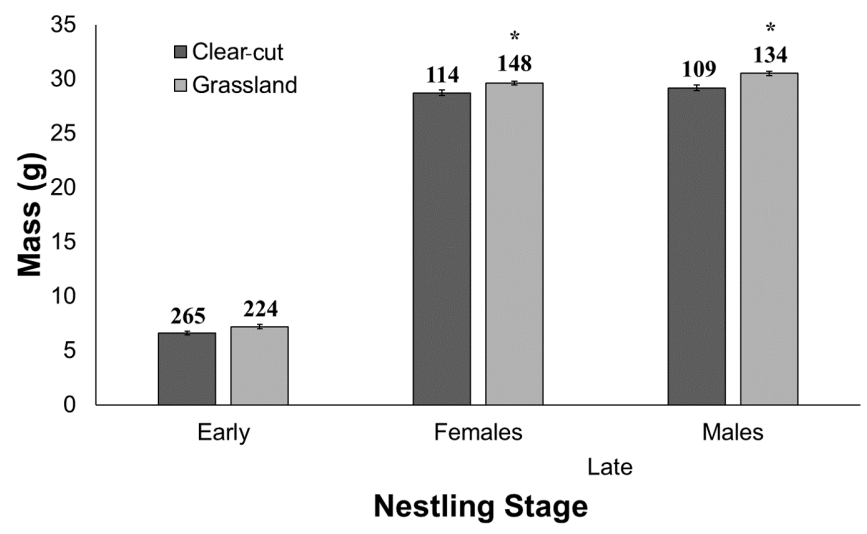

predation risk is unlikely to explain our results. It is also unlikely that bluebirds simply preferred different prey types in the habitats because according to foraging theory (Krebs and Davies 1993), individuals should always use the most profitable and nutritious items when they encounter them. Because we did not measure abundance of insects directly in the habitats, we cannot be certain that this was the cause of limited food deliveries in clear-cuts or whether accessibility to prey played a role, e.g., dense vegetation structure hindered the detection of prey. Below, we discuss the details of provisioning patterns and the potential role that vegetation structure and perches might have in determining access to prey.

\section{Prey volume}

Bluebird parents of both sexes brought larger prey as nestlings grew, which is similar to the pattern in some other passerines (Adler and Ritchison 2011, Wiebe and Slagsvold 2014). This makes sense because small nestlings have difficulty swallowing large items but older nestlings with higher energy demands are most efficiently fed with large prey (Slagsvold and Wiebe 2007, Stalwick and Wiebe 2019). Prey size did not differ between habitat types when nestlings were less than five days old, but at older nestling stages, female parents in clear-cuts brought larger prey than females in grasslands. All else equal, larger prey in clear-cuts would make foraging more profitable there if nestlings could be satiated with fewer deliveries but the lower fledging mass in clearcuts suggests the total amount of food delivered was less than in grasslands.

We also found that males generally brought larger prey than females, which is the same sex-bias documented in some other passerines such as Pied Flycatchers (Ficedula hypoleuca) and Blue Tits (Bańbura et al. 2001, Wiebe and Slagsvold 2014). Females are probably more attuned to the needs of their nestlings (Budden 
and Beissinger 2009, García-Navas et al. 2014, Liu et al. 2014) and may therefore bring smaller prey suitable for young nestlings to ensure they get sufficient food. Alternatively, females may not be intentionally searching for small prey but only bring it because they may be spending more time looking after the nestlings in the box, i.e., brooding, than males and may have less time to find larger prey (Wiebe and Slagsvold 2009). Prey size was also correlated with structural body size in female but not male Mountain Bluebirds possibly because females with larger bills were able to handle larger insects easier than small females.

\section{Prey type}

The taxa of prey we identified have been recorded for Mountain Bluebirds previously (review in Johnson and Dawson 2019) but larva and spiders were used more, and grasshoppers, cicadas, and adult Lepidoptera were used less compared to the diets reported in Power (1980) and Herlugson (1982). In our study, larvae were the predominant prey in both nestling stages in both habitats, composing $34 \%$ of all prey items. The proportion of prey types did not differ between habitats when nestlings were young, and apparently parents focused on the digestible and nutritious larvae and spiders at this stage. However, the diet of older nestlings contained proportionately more larvae and spiders in clear-cuts compared to grasslands, where the diet became more diverse with beetles, grasshoppers, and adult Lepidoptera. The extent to which these shifts were driven by changing seasonal abundance of different insects needs to be determined by direct sampling of prey in each habitat. Nevertheless, it appeared although there were nutritious prey types available in clear-cuts, there was less total food there compared to grasslands. Few studies have examined insect biodiversity and abundance in clear-cuts compared to grasslands, so patterns are difficult to generalize. There were more butterflies in clear-cut habitats compared to grasslands in Sweden (Jonason et al. 2010) but fewer moths in clear-cuts in Oregon, USA (Highland et al. 2013), so the overall effect of anthropogenic disturbance on the abundance of Lepidoptera and their larvae is probably related to the particular landscape.

Grasshoppers are an important food source for Mountain Bluebirds elsewhere, making up to $33 \%-41 \%$ of the nestling diet (Power 1980, Herlugson 1982) but they made up only about $6 \%$ of the diet in our study (Appendix 2), perhaps because of the relatively high latitude of our study sites. Grasshoppers did not seem to emerge in sizable numbers until after nestlings fledged (July), and Pinkowski (1978) also reported that grasshoppers became more common in the diet of Eastern Bluebird (Sialia sialis) nestlings in late summer. Instead, beetles made up $25 \%$ of prey items in our study and appeared to be prominent alternate prey in grasslands. Beetles seem to be less nutritious and digestible than larvae and spiders, but if such alternate prey were abundant and easy to hunt, they could provide crucial energy for nestlings during times of peak demand. Similarly, Wood Warblers (Phylloscopus sibilatrix) brought more spiders early in the nestling period but switched to larger, winged insects as nestlings got older (Maziarz and Wesołowski 2010), which may provide efficient energy for older nestlings.

\section{Delivery rates}

There is little information in the literature on prey deliveries to small bluebird nestlings younger than five days, but the rates we observed to older nestlings were within the range reported in other studies cited in Johnson and Dawson (2019). Delivery rates to older nestlings were higher in grasslands than in clear-cuts, which suggests that prey was more abundant or more easily found in grasslands. In some cases, however, frequent deliveries are an attempt by parents under stress to compensate for small or nutritionally poor food items as in some seabirds (Kadin et al. 2016), European Starlings (Sturnus vulgaris; Wright et al. 1998) and titmice (Wiebe and Slagsvold 2015). Indeed, the proportion of high quality prey (larvae and spiders) in the diet was lower in grasslands than in clear-cuts at the late nestling stage. However, the high delivery rate of parent bluebirds in grasslands did not seem to be only compensatory because fledglings reared in grasslands were heavier than those from clear-cuts. Thus, parents in grasslands were able to deliver more food in total to their nestlings. The overall productivity (fledglings produced/egg laid) was about $9 \%$ higher in grasslands and fledglings were about $4 \%$ heavier there compared to those from clear-cuts (Stalwick 2018). A higher mass at fledging increases long-term survival and recruitment in many species (Monrós et al. 2002; review in Ronget et al. 2018) so fledglings from clear-cuts potentially have lower survival but this needs to be quantified with telemetry and tracking of individuals.

Delivery rates in grasslands also increased with brood size as might be expected with the increased demand, and the same pattern occurs in many other insectivorous passerines such as Blue Tits (Stauss et al. 2005, García-Navas and Sanz 2010) and Grasshopper Sparrows (Ammodramus savannarum; Adler and Ritchison 2011). However, during the older nestling stage, females in clear-cuts did not increase their delivery rate with brood size, which could mean they had reached their peak provisioning rate due to a lower availability of food (by whatever mechanism) in clear-cuts. Similarly, Blue Tits that lived in a lower quality habitat were unable to increase provisioning rates with larger broods whereas Blue Tits in the higher quality habitat were able to do so (Stauss et al. 2005).

With respect to sex differences, females in our study provisioned less than males at the youngest nestling stage but more than males when nestlings were older. Other studies of Mountain Bluebirds have also reported that females fed the nestlings more often than the males later in the nestling period, although males may have the same or higher feeding rates during the early nestling period when females brood (Power 1980, Balenger et al. 2007). Pinkowski (1978) also reported that Eastern Bluebird males decreased their delivery rate later in the nestling period. This decrease in delivery rate of males in our study might have been related to the fact that they were bringing larger prey than females overall, similar to the case where Great Reed-Warblers (Acrocephalus arundinaceus) made fewer deliveries when prey load sizes were larger (Sejberg et al. 2000). Few attributes of parents themselves, neither age nor color affected delivery rates although at the older nestling stage, there was a negative relationship between body condition and delivery rate. This corresponds to results in Balenger et al. (2007) and Morrison et al. (2014) where color was not associated with provisioning rate for female Mountain Bluebirds. Perhaps parents were trading off effort for the current brood with their own body condition, but what might trigger different investment strategies needs further investigation with food supplementation experiments and long-term data on lifetime reproduction to elucidate. 


\section{Effects of habitat structure}

Trees and shorter perches are used by birds that scan-and-pounce on prey to forage (Power 1980, Robertson 2012) because they may increase visibility of prey and reduce energy expenditure compared with hovering. Clear-cuts had more short- and medium-height perches than grasslands as a result of more shrubs and saplings, so that structure should have made perch-hunting more efficient, yet delivery rates were lower there. This indicates that prey were less available in clear-cuts although whether it was insect abundance per se that was lower or whether the insects were just more obscured in clear-cuts because of higher shrub density needs to be teased apart in the future by direct sampling of insect abundance. In general, bluebirds prefer short and sparse vegetation for foraging, either because dense vegetation makes it harder to see and reach prey items on the ground, or because visibility is reduced making it more difficult for bluebirds to detect predators (Power 1980).

\section{CONCLUSION}

Future studies should measure the abundance of arthropod species in grassland and clear-cut habitats throughout the nestling period to determine the degree to which diets and delivery rates reflect local prey abundance versus hunting effort or success by various species of insectivorous birds. Bluebirds only use clearcuts for about six years postharvest and it makes little sense for managers to manipulate clear-cuts to preserve those anthropogenically created habitats at early successional stages. Rather, our study highlights that managers should be aware that clear-cuts may not always provide equivalent food types or amounts as natural grasslands. Data on the relationship between fledging mass and survival in bluebirds would also help to quantify the extent to which nutrition and food supply might decrease fitness within clear-cuts, whether clear-cuts are acting as ecological traps, and whether the proportion of clear-cut habitat should then be limited on the landscape.

Responses to this article can be read online at: http://www.ace-eco.org/issues/responses.php/1333

\section{Acknowledgments:}

Thanks to the Scherrers, Arendals, and Bridge Creek Ranch for access to their property. L. Berzins provided assistance and advice with the spectrometer and $S$. Srayko helped with insect identification. The study was funded by a Natural Sciences and Engineering Research Council of Canada (grant 203177) to KLW.

\section{LITERATURE CITED}

Adler, J., and G. Ritchison. 2011. Provisioning behavior of male and female Grasshopper Sparrows. Wilson Journal of Ornithology 123:515-520. http://dx.doi.org/10.1676/10-150.1

Arnold, K. E., S. L. Ramsay, C. Donaldson, and A. Adam. 2007. Parental prey selection affects risk-taking behaviour and spatial learning in avian offspring. Proceedings of the Royal Society BBiological Sciences 274:2563-2569. http://dx.doi.org/10.1098/ rspb.2007.0687
Balenger, S. L., L. S. Johnson, J. L. Brubaker, and E. Ostlind. 2007. Parental effort in relation to structural plumage coloration in the Mountain Bluebird (Sialia currucoides). Ethology 113:838-846. http://dx.doi.org/10.1111/j.1439-0310.2007.01386. $\mathrm{x}$

Bańbura, J., J. Blondel, H. de Wilde-Lambrechts, M.-J. Galan, and M. Maistre. 1994. Nestling diet variation in an insular Mediterranean population of Blue Tits Parus Caeruleus: effects of years, territories and individuals. Oecologia 100:413-420. http://dx.doi.org/10.1007/BF00317863

Bańbura, J., M. M. Lambrechts, J. Blondel, P. Perret, and M. Cartan-Son. 1999. Food handling time of Blue Tit chicks: constraints and adaptation to different prey types. Journal of Avian Biology 30:263-270. http://dx.doi.org/10.2307/3677352

Bańbura, J., P. Perret, J. Blondel, A. Sauvages, M. J. Galan, and M. M. Lambrechts. 2001. Sex differences in parental care in a Corsican Blue Tit Parus caeruleus population. Ardea 89:517-526.

Barker, D., M. P. Fitzpatrick, and E. S. Dierenfeld. 1998. Nutrient composition of selected whole invertebrates. Zoo Biology 17:123-134. http://dx.doi.org/10.1002/(SICI)1098-2361(1998)17:2<123:: AID-ZOO7>3.0.CO;2-B

Berzins, L. L., and R. D. Dawson. 2016. Experimentally altered plumage brightness of female Tree Swallows: a test of the differential allocation hypothesis. Behaviour 153:525-550. http:// dx.doi.org/10.1163/1568539X-00003354

Budden, A. E., and S. R. Beissinger. 2009. Resource allocation varies with parental sex and brood size in the asynchronously hatching Green-rumped Parrotlet (Forpus passerinus). Behavioral Ecology and Sociobiology 63:637-647. http://dx.doi.org/10.1007/ s00265-008-0698-x

Bukkens, S. G. F. 1997. The nutritional value of edible insects. Ecology of Food and Nutrition 36:287-319. http://dx.doi. org/10.1080/03670244.1997.9991521

Daunt, F., S. Wanless, M. P. Harris, L. Money, and P. Monaghan. 2007. Older and wiser: improvements in breeding success are linked to better foraging performance in European Shags. Functional Ecology 21:561-567. http://dx.doi.org/10.1111/ j.1365-2435.2007.01260.X

De Santo, T. L., and M. F. Willson. 2001. Predator abundance and predation of artificial nests in natural and anthropogenic coniferous forest edges in southeast Alaska. Journal of Field Ornithology 72:136-149. http://dx.doi.org/10.1648/0273-8570-72.1.136

Desrochers, A. 1992. Age and foraging success in European Blackbirds: variation between and within individuals. Animal Behaviour 43:885-894. http://dx.doi.org/10.1016/S0003-3472(06) 80002-3

Donald, P. F., L. B. Muirhead, D. L. Buckingham, A. D. Evans, W. B. Kirby, and D. J. Gruar. 2001. Body condition, growth rates and diet of Skylark Alauda arvensis nestlings on lowland farmland. Ibis 143:658-669. http://dx.doi.org/10.1111/j.1474-919X.2001. tb04894.x

García-Navas, V., E. S. Ferrer, and J. J. Sanz. 2013. Prey choice, provisioning behaviour, and effects of early nutrition on nestling phenotype of titmice. Ecoscience 20:9-18. http://dx.doi. org/10.2980/20-1-3545 
García-Navas, V., E. S. Ferrer, and E. Serrano-Davies. 2014. Experimental evidence for parental, but not parentally biased, favouritism in relation to offspring size in Blue Tits Cyanistes caeruleus. Ibis 156:404-414. http://dx.doi.org/10.1111/ibi.12140

García-Navas, V., and J. J. Sanz. 2010. Flexibility in the foraging behavior of Blue Tits in response to short-term manipulations of brood size. Ethology 116:744-754. http://dx.doi.org/10.1111/ j.1439-0310.2010.01788.x

Graveland, J., and T. Van Gijzen. 1994. Arthropods and seeds are not sufficient as calcium sources for shell formation and skeletal growth in passerines. Ardea 82:299-314.

Herlugson, C. J. 1982. Food of adult and nestling Western and Mountain Bluebirds. Murrelet 63:59-65. http://dx.doi. org/10.2307/3533829

Hidalgo-Garcia, S. 2006. The carotenoid-based plumage coloration of adult Blue Tits Cyanistes caeruleus correlates with the health status of their brood. Ibis 148:727-734. http://dx.doi. org/10.1111/j.1474-919X.2006.00575.X

Highland, S. A., J. C. Miller, and J. A. Jones. 2013. Determinants of moth diversity and community in a temperate mountain landscape: vegetation, topography, and seasonality. Ecosphere 4:1-22. http://dx.doi.org/10.1890/ES12-00384.1

Holt, R. F., and K. Martin. 1997. Landscape modification and patch selection: the demography of two secondary cavity nesters colonizing clearcuts. Auk 114:443-455. http://dx.doi.org/10.2307/4089245

Ibbe, M., P. Milberg, A. Tunér, and K.-O. Bergman. 2011. History matters: impact of historical land use on butterfly diversity in clear-cuts in a boreal landscape. Forest Ecology and Management 261:1885-1891. http://dx.doi.org/10.1016/j.foreco.2011.02.011

Johnson, L. S., and R. D. Dawson. 2019. Mountain Bluebird (Sialia currucoides), version 3.0. In P. G. Rodewald, editor. The birds of North America. Cornell Lab of Ornithology, Ithaca, New York, USA.

Jonason, D., P. Milberg, and K.-O. Bergman. 2010. Monitoring of butterflies within a landscape context in south-eastern Sweden. Journal for Nature Conservation 18:22-33. http://dx.doi. org/10.1016/j.jnc.2009.02.001

Kadin, M., O. Olsson, J. Hentati-Sundberg, E. W. Ehrning, and T. Blenckner. 2016. Common Guillemot Uria aalge parents adjust provisioning rates to compensate for low food quality. Ibis 158:167-178. http://dx.doi.org/10.1111/ibi.12335

Krebs, J. R., and N. B. Davies. 1993. An introduction to behavioural ecology. Third edition. Blackwell Science, London, UK.

Korpela, E., T. Hyvönen, and M. Kuussaari. 2015. Logging in boreal field-forest ecotones promotes flower-visiting insect diversity and modifies insect community composition. Insect Conservation and Diversity 8(2):152-162. http://dx.doi.org/10.1111/ icad.12094

Kuznetsova A., P. B. Brockhoff, and R. H. B. Christensen. 2017. lmerTest package: tests in linear mixed effects models. Journal of Statistical Software 82:1-26. http://dx.doi.org/10.18637/jss.v082. i13
Labocha, M. K., and J. P. Hayes. 2012. Morphometric indices of body condition in birds: a review. Journal of Ornithology 153:1-22. http://dx.doi.org/10.1007/s10336-011-0706-1

Liu, C., B. Du, N. Liu, S. Bao, and S. Zhang. 2014. Sex-specific parental care strategies via nestling age: females pay more attention to nestling demands than males do in the Horned Lark, Eremophila alpestris. Zoological Science 31:348-352. http://dx. doi.org/10.2108/zs130175

Maia, R., C. M. Eliason, P. P. Bitton, S. M. Doucet, and M. D. Shawkey. 2013. pavo: an R Package for the analysis, visualization and organization of spectral data. Methods in Ecology and Evolution 4:906-913. http://dx.doi.org/10.1111/2041-210X.12069

Martin, T. E., J. Scott, and C. Menge. 2000. Nest predation increases with parental activity: separating nest site and parental activity effects. Proceedings of the Royal Society B: Biological Sciences 267:2287-2293. http://dx.doi.org/10.1098/rspb.2000.1281

Maziarz, M., and T. Wesołowski. 2010. Timing of breeding and nestling diet of Wood Warbler Phylloscopus sibilatrix in relation to changing food supply. Bird Study 57:540-552. http://dx.doi. org/10.1080/00063657.2010.512954

Monrós, J. S., E. J. Belda, and E. Barba. 2002. Post-fledging survival of individual Great Tits: the effect of hatching date and fledging mass. Oikos 99:481-488. http://dx.doi.org/10.1034/ j.1600-0706.2002.11909.x

Montgomerie, R. 2006. Analyzing colors. Pages 90-147 in G. E. Hill and K. J. McGraw, editors. Bird coloration. Volume 1: mechanisms and measurements. Harvard University Press, Cambridge, Massachusetts, USA.

Morrison, A., N. J. Flood, and M. W. Reudink. 2014. Reproductive correlates of plumage coloration of female Mountain Bluebirds. Journal of Field Ornithology 85:168-179. https://doi.org/10.1111/jofo.12058

Musgrove, A. B., and K. L. Wiebe. 2014. Northern Flickers increase provisioning rates to raise more but poorer quality offspring when given experimentally enlarged broods. Auk 131:571-582. http://dx.doi.org/10.1642/AUK-14-51.1

Pinkowski, B. C. 1978. Feeding of nestling and fledgling Eastern Bluebirds. Wilson Bulletin 90:84-98.

Power, H. W. 1980. The foraging behavior of Mountain Bluebirds with emphasis on sexual foraging differences. Ornithological Monographs 28:1-72. http://dx.doi.org/10.2307/40166764

Pyle, P. 1997. Identification guide to North American birds, part 1. Slate Creek Press, Bolinas, California, USA.

R Core Team. 2017. R: A language and environment for statistical computing. R Foundation for Statistical Computing, Vienna, Austria. [online] URL: https://www.R-project.org/

Ramsay, S. L., and D. C. Houston. 2003. Amino acid composition of some woodland arthropods and its implications for breeding tits and other passerines. Ibis 145:227-232. http://dx.doi. org/10.1046/j.1474-919X.2003.00133.X

Razeng, E., and D. M. Watson. 2015. Nutritional composition of the preferred prey of insectivorous birds: popularity reflects 
Avian Conservation and Ecology 14(1): 10

quality. Journal of Avian Biology 46(1):89-96. http://dx.doi. org/10.1111/jav.00475

Rising, J. D., and K. M. Somers. 1989. The measurement of overall body size in birds. Auk 106:666-674. http://dx.doi. org/10.2307/4087777

Robertson, B. A. 2012. Investigating targets of avian habitat management to eliminate an ecological trap. Avian Conservation and Ecology 7(2):2.

Ronget, V., J.-M. Gaillard, T. Coulson, M. Garratt, F. Gueyffier, J. C. Lega, and J. F. Lemaître. 2018. Causes and consequences of variation in offspring body mass: meta-analyses in birds and mammals. Biological Reviews 93:1-27. http://dx.doi.org/10.1111/ brv. 12329

Rudnicky, T. C., and M. L. Hunter. 1993. Avian nest predation in clearcuts, forests, and edges in a forest-dominated landscape. Journal of Wildlife Management 57:358-364. http://dx.doi. org/10.2307/3809434

Sejberg, D., S. Bensch, and D. Hasselquist. 2000. Nestling provisioning in polygynous Great Reed Warblers (Acrocephalus arundinaceus): do males bring larger prey to compensate for fewer nest visits? Behavioral Ecology and Sociobiology 47:213-219. http://dx.doi.org/10.1007/s002650050658

Serrano-Davies, E., and J. J. Sanz. 2017. Habitat structure modulates nestling diet composition and fitness of Blue Tits Cyanistes caeruleus in the Mediterranean region. Bird Study 64:295-305. http://dx.doi.org/10.1080/00063657.2017.1357678

Skipper, B. R., and D. H. Kim. 2013. Provisioning rate, dietary composition, and prey selection of breeding Bobolinks and Grasshopper Sparrows. Western North American Naturalist 73:35-40. http://dx.doi.org/10.3398/064.073.0103

Slagsvold, T., and K. L. Wiebe. 2007. Hatching asynchrony and early nestling mortality: the feeding constraint hypothesis. Animal Behaviour 73:691-700. http://dx.doi.org/10.1016/j.anbehav.2006.05.021

Stalwick, J. A. 2018. Provisioning patterns, diet, and reproduction of Mountain Bluebirds (Sialia currucoides) in clearcut versus grassland habitats. Thesis, University of Saskatchewan, Saskatoon, Saskatchewan, Canada.

Stalwick, J. A., and K. L. Wiebe. 2019. Prey size and nestling gape size affect allocation within broods of the Mountain Bluebird. Journal of Ornithology 160:145-154. https://doi.org/10.1007/ s10336-018-1603-7 http://dx.doi.org/10.1007/s10336-018-1603-7

Stauss, M. J., J. F. Burkhardt, and J. Tomiuk. 2005. Foraging flight distances as a measure of parental effort in Blue Tits Parus caeruleus differ with environmental conditions. Journal of Avian Biology 36:47-56. http://dx.doi.org/10.1111/j.0908-8857.2005.02855. $\mathrm{x}$

Tilgar, V., R. Mänd, P. Kilgas, and S. J. Reynolds. 2005. Chick development in free-living Great Tits Parus major in relation to calcium availability and egg composition. Physiological and Biochemical Zoology 78:590-598. http://dx.doi.org/10.1086/430690

Wiebe, K. L. 2016. Interspecific competition for nests: prior ownership trumps resource holding potential for Mountain Bluebird competing with Tree Swallow. Auk 133:512-519. https:// doi.org/10.1642/AUK-16-25.1

Wiebe, K. L., and T. Slagsvold. 2009. Parental sex differences in food allocation to junior brood members as mediated by prey size. Ethology 115:49-58. http://dx.doi.org/10.1111/j.1439-0310.2008.01580. $\mathrm{x}$

Wiebe, K. L., and T. Slagsvold. 2014. Prey size increases with nestling age: are provisioning parents programmed or responding to cues from offspring? Behavioral Ecology and Sociobiology 68:711-719

Wiebe, K. L., and T. Slagsvold. 2015. Foraging trade-offs between prey size, delivery rate and prey type: how does niche breadth and early learning of the foraging niche affect food delivery? Ethology 121:1010-1017. http://dx.doi.org/10.1111/eth.12411

Wiebe, K. L., and M. N. Vitousek. 2015. Melanin plumage ornaments in both sexes of Northern Flicker are associated with body condition and predict reproductive output independent of age. Auk 132:507-517. http://dx.doi.org/10.1642/AUK-14-281.1

Wright, J., C. Both, P. A. Cotton, and D. Bryant. 1998. Quality vs. quantity: energetic and nutritional trade-offs in parental provisioning strategies. Journal of Animal Ecology 67:620-634. http://dx.doi.org/10.1046/j.1365-2656.1998.00221.x
Editor-in-Chief: Keith A.Hobson

Subject Editor: Katie E.Sieving
Sponsored by the Society of Canadian Ornithologists and Bird Studies Canada Parrainée par la Société des ornithologistes du Canada et Études d'oiseaux Canada

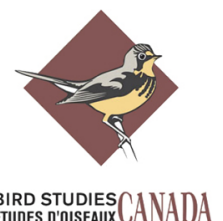


Appendix 1. Vegetation ground cover in clear-cut and grassland habitats.

Table A1.1. The proportion of ground cover type within $1 \mathrm{~m}^{2}$ plots near each nestbox of Mountain Bluebirds (Sialia currucoides). At each box, the average cover based on two plots was calculated and shown are the overall averages from 44 clear-cut boxes and 52 grassland boxes. "Other debris" refers to lichen and dead plants.

\begin{tabular}{lll}
\hline \hline Ground cover Type & Clear-cuts & Grasslands \\
\hline Bare Ground & $0.08 \pm 0.01$ & $0.18 \pm 0.02$ \\
Woody Debris & $0.13 \pm 0.01$ & $0.003 \pm 0.001$ \\
Grass & $0.16 \pm 0.01$ & $0.34 \pm 0.02$ \\
Other Debris & $0.24 \pm 0.01$ & $0.26 \pm 0.02$ \\
Asteraceae & $0.05 \pm 0.01$ & $0.08 \pm 0.01$ \\
Caryophyllaceae & $0.004 \pm 0.001$ & $0.003 \pm 0.002$ \\
Cornaceae & $0.005 \pm 0.002$ & 0 \\
Ericaceae & $0.05 \pm 0.01$ & $0.0003 \pm 0.003$ \\
Fabaceae & $0.06 \pm 0.01$ & $0.07 \pm 0.01$ \\
Geraniaceae & $0.002 \pm 0.002$ & $0.003 \pm 0.002$ \\
Lamiaceae & 0 & $0.01 \pm 0.002$ \\
Liliaceae & $0.01 \pm 0.001$ & 0 \\
Onagraceae & $0.03 \pm 0.004$ & 0 \\
Pinaceae & $0.01 \pm 0.002$ & 0 \\
Rosaceae & $0.1 \pm 0.01$ & $0.02 \pm 0.004$ \\
Rubiaceae & $0.02 \pm 0.003$ & $0.01 \pm 0.002$ \\
Salicaceae & $0.01 \pm 0.002$ & $0.001 \pm 0.0005$ \\
Other Plants & $0.02 \pm 0.003$ & $0.02 \pm 0.003$ \\
\hline
\end{tabular}


Appendix 2. Prey types used by Mountain Bluebird (Sialia currucoides) parents to feed their nestlings.

Table A2.1. The percentage of all prey types that were fed to nestlings in clear-cuts and grasslands. Cicadas were separated from Hemiptera because their bodies were relatively large and bulky. Unknown refers to (usually small), unidentifiable prey items or cases where parents brought multiple items that could not be distinguished. There were 2205 prey items brought in clear-cuts and 2662 prey items brought in grasslands. Prey types are roughly ordered in decreasing abundance.

\begin{tabular}{lll}
\hline \hline Prey Type & Clear-cuts & Grasslands \\
\hline Larva & $40.54 \%$ & $28.21 \%$ \\
Spider & $26.44 \%$ & $15.18 \%$ \\
Coleoptera & $9.84 \%$ & $25.21 \%$ \\
Unknown & $6.53 \%$ & $11.46 \%$ \\
Orthoptera & $5.49 \%$ & $6.31 \%$ \\
Hymenoptera & $4.63 \%$ & $4.40 \%$ \\
Lepidoptera & $3.40 \%$ & $2.82 \%$ \\
Diptera & $1.77 \%$ & $2.52 \%$ \\
Odonata & $0.63 \%$ & $1.54 \%$ \\
Cicada & $0.18 \%$ & $1.43 \%$ \\
Ephemeroptera & $0.09 \%$ & $0.41 \%$ \\
Trichoptera & $0.09 \%$ & $0.3 \%$ \\
Annelida & $0.27 \%$ & $0.04 \%$ \\
Hemiptera & $0.09 \%$ & $0.04 \%$ \\
Neuroptera & $0 \%$ & $0.08 \%$ \\
Myriapoda & $0 \%$ & $0.04 \%$ \\
Plecoptera & $0 \%$ & $0.04 \%$ \\
\hline
\end{tabular}

